\title{
Hot and late: clumped isotopes in Middle Jurassic calcite-cemented concretions from Skye
}

\author{
RICHMAL B. PAXTON, JULIAN E. ANDREWS, PAUL F. \\ DENNIS AND ALINA D. MARCA
}

University of East Anglia

Presenting Author: r.paxton@uea.ac.uk

Decimetre-scale, calcite-cemented concretions hosted in the Middle Jurassic Valtos Sandstone Formation of Skye, Scotland should record geochemically the origin of pore waters from which they grew. On the basis of traditional stable isotope data, these cements have long been thought to form from meteoric water of Middle to Upper Jurassic age [1]; however, concretions from Valtos in Trotternish had some unusually negative $\delta^{18} \mathrm{O}_{\text {calcite }}$ compositions, complicating interpretations.

Recent availability of clumped isotope measurements mean that previous assumptions about palaeotemperatures and pore fluid compositions can now be tested.

Measurements of one concretion show centre to edge temperatures trending from $50^{\circ} \mathrm{C}$ to $80^{\circ} \mathrm{C}$. Using these temperatures and measured $\delta^{18} \mathrm{O}_{\text {calcite }}$ values, pore water $\delta^{18} \mathrm{O}$ were calculated, showing a centre to edge evolution from $-12 \%$ to $+3 \% 0_{\text {VSMOW }}$. Significantly, the starting composition of $-12 \%{ }_{\text {VSMOW }}$ is incompatible with Jurassic meteoric water composition $\left(<-6 \%{ }_{\text {VSMOW }}[2]\right)$. Instead, $-12 \% 0_{\text {VSMOW }}$ is exactly the composition of Hebridean Palaeocene meteoric water as demonstrated by a number of classic studies. Concretion growth thus began in the Palaeocene.

The calculated temperatures of this phase of concretionary cement basinwide (across $75 \mathrm{~km}$ ) are higher than previously assumed, suggesting growth initiated at either deeper burial (or higher geotherm) or from warmer pore waters than was previously speculated. The sharp transition of the $\sim 30^{\circ} \mathrm{C}$ temperature increase from 50 to $80^{\circ} \mathrm{C}$ raises the possibility that Palaeocene pore waters were heated as the Jurassic sandstones were rapidly buried under ca. $1200 \mathrm{~m}$ of basaltic Palaeocene lavas of the Hebridean Igneous Province.

The evolution in pore water composition from $-12 \%$ to $+3 \%{ }_{\text {VSMOW }}$ suggests a water-rock interaction signal, potentially with overlying lavas.

The new clumped isotope data fundamentally alters the interpretation of sandstone concretion growth in this region, showing that the cements formed much later and at higher temperatures than previously assumed. The study exemplifies the power of the carbonate clumped isotope paleothermometer in investigating burial cementation and diagenesis in both sandstones and limestones.

References

[1] Wilkinson (1993), Journal of the Geological Society of London 150, 57-66.

[2] Hudson \& Andrews (1987), Geological Society of London, Special Publication 36, 259-276. 